\title{
Influence of starter protein content on growth of dairy calves in an enhanced early nutrition program ${ }^{1}$
}

\author{
J. A. Stamey, ${ }^{{ }^{2}}$ N. A. Janovick, ${ }^{\star 3}$ A. F. Kertz, $\dagger^{3}$ and J. K. Drackley ${ }^{\star 4}$ \\ *Department of Animal Sciences, University of Illinois, Urbana 61801 \\ †Andhil LLC, St. Louis, MO 63122
}

\begin{abstract}
Our objectives were to determine the effect of starter crude protein $(\mathrm{CP})$ content on growth of Holstein calves from birth to 10 wk of age in an enhanced early nutrition program, and to compare the enhanced program to a conventional milk replacer program. Calves (64 female, 25 male) were assigned to 3 treatments in a randomized block design: 1) conventional milk replacer (20\% CP, 20\% fat) plus conventional starter [19.6\% $\mathrm{CP}$, dry matter (DM) basis], 2) enhanced milk replacer (28.5\% CP, $15 \%$ fat) plus conventional starter, and 3 ) enhanced milk replacer plus high-CP starter $(25.5 \%$ $\mathrm{CP}, \mathrm{DM}$ basis). Calves began treatments $(\mathrm{n}=29,31$, and 29 for treatments 1 to 3 ) at $3 \mathrm{~d}$ of age. Conventional milk replacer $(12.5 \%$ solids $)$ was fed at $1.25 \%$ of birth body weight (BW) as DM daily in 2 feedings from wk 1 to 5 and at $0.625 \%$ of birth BW once daily during wk 6 . Enhanced milk replacer (15\% solids) was fed at $1.5 \%$ of BW as DM during wk 1 and $2 \%$ of BW as DM during wk 2 to 5 , divided into 2 daily feedings. During wk 6 , enhanced milk replacer was fed at $1 \%$ of BW as DM once daily. Calves were weaned at d 42 . Starter was available for ad libitum intake starting on d 3. Starter intake was greater for calves fed conventional milk replacer. For calves fed enhanced milk replacer, starter intake tended to be greater for calves fed enhanced starter. During the weaning period, enhanced starter promoted greater starter DM intake than the conventional starter. Over the 10 -wk study, the average daily gain of BW $(0.64,0.74$, and $0.80 \mathrm{~kg} / \mathrm{d})$ was greater for calves fed enhanced milk replacer with either starter and, for calves fed enhanced milk replacer, tended to be greater for calves fed high-CP starter. Rates of

\footnotetext{
Received October 28, 2011.

Accepted January 12, 2012.

${ }^{1}$ Supported in part by USDA-CSREES and state funds appropriated

${ }^{2}$ Current address: Department of Dairy Science, Virginia Tech

${ }^{3}$ Current address: Milk Specialties Global, Carpentersville, IL.

${ }^{4}$ Corresponding author: drackley@illinois.edu
} to the Illinois Agricultural Experiment Station, and by Milk Specialties Co., Dundee, IL. University, Blacksburg.
\end{abstract}

change in withers height, body length, and heart girth were greater for calves fed enhanced milk replacer but did not differ between starter $\mathrm{CP}$ concentrations. The postweaning BW for enhanced milk replacer treatments was greater for calves receiving the enhanced starter at wk $8(73.7,81.3$, and $85.8 \mathrm{~kg})$ and wk 10 (88.0, 94.9, and $99.9 \mathrm{~kg}$ ). Starter CP content did not affect height, length, or heart girth within enhanced milk replacer treatments. Regression analysis showed that gain of BW during the first week postweaning (wk 7) increased with greater 3-d mean starter intake in the week before weaning. Starter with 25.5\% CP (DM basis) provided modest benefits in starter intake (particularly around weaning) and growth for dairy calves in an enhanced early nutrition program compared with a conventional starter $(19.6 \% \mathrm{CP})$.

Key words: calf, growth, milk replacer, starter

\section{INTRODUCTION}

Traditionally, calf rearing programs have been designed to decrease the cost of raising replacement heifers by encouraging early intake of dry feed (starter), thereby reducing the length of the milk-feeding period. Research during the last decade has led to increased interest in implementation of so-called accelerated, enhanced early nutrition, or intensive feeding programs in which greater amounts of milk (Jasper and Weary, 2002; Khan et al., 2007) or milk replacer (Diaz et al., 2001; Blome et al., 2003; Hill et al., 2006) solids are fed. These programs have the potential to increase growth rates and decrease the age at first calving, potentially providing a greater long-run economic benefit to producers (Davis Rincker et al., 2011).

Promoting early consumption of dry feed is a priority in young calves to stimulate development of the reticulorumen (Warner et al., 1956) and ease the weaning transition from a liquid diet to a dry diet (Hodgson, 1971; Leaver and Yarrow, 1972). To minimize nutritional stress on the calf, enough dry feed must be consumed before weaning to at least supply maintenance requirements for energy and MP (Hodgson, 1971; Leaver and Yarrow, 1972). Although calves fed greater amounts of 
milk (Jasper and Weary, 2002) or milk replacer (Diaz et al., 2001; Blome et al., 2003; Bartlett et al., 2006) have increased ADG and efficiency of gain during the milk feeding period, it has long been known that increased feeding rates of milk or milk replacer decreases consumption of starter during the milk feeding period (Hodgson, 1971; Leaver and Yarrow, 1972; Jenny et al., 1982; Huber et al., 1984). Lower starter intake by calves fed enhanced milk replacers (Cowles et al., 2006; Hill et al., 2006, 2008) may potentially limit rumen development and decrease gains as the calf transitions at weaning, through both lower total nutrient intake and lower ruminal digestibility (Terré et al., 2006, 2007; Hill et al., 2010).

One potential approach to counteract this weaning stall-out period is to increase provision of MP from starter to prevent limiting AA with lower starter intake. Because CP content of milk replacer must be increased relative to conventional milk replacers to support the greater rates of lean tissue growth, it has been assumed that starter $\mathrm{CP}$ also would need to be increased. The National Research Council (NRC, 2001) recommended $18 \% \mathrm{CP}$ on a DM basis, equivalent to a $16 \% \mathrm{CP}$ starter on an as-fed basis, for conventionally reared calves. The NRC model indicates that 18\% CP (DM basis) in starter should be adequate for calves fed enhanced milk replacer, and that energy supply rather than CP supply would be limiting growth. However, data needed to determine whether an increased CP or MP concentration in starter is necessary are inconclusive. Hill et al. (2007) found no effects of altering MP supply in calves fed a moderately increased rate $(680 \mathrm{~g} / \mathrm{d})$ of milk replacer containing $26 \% \mathrm{CP}$ and $17 \%$ fat.

The objectives of this experiment were to quantify the effect of increased starter CP content on growth of dairy calves from birth to $10 \mathrm{wk}$ of age in an enhanced early nutrition program and to compare an enhanced early nutrition program to a conventional milk replacer program. Our hypothesis was that a higher CP concentration in the starter would increase MP supply, which would help maintain growth at and after weaning for calves in an enhanced early nutrition program.

\section{MATERIALS AND METHODS}

\section{Calves and Housing}

All procedures were conducted under protocols approved by the University of Illinois Institutional Animal Care and Use Committee. Eighty-nine Holstein calves (64 female, 25 male) born at the University of Illinois Dairy Research and Teaching Unit between March 7, 2004 and October 8, 2004 were assigned to 3 treatments in a randomized block design. Approximately equal numbers of calves and calf sexes were maintained among treatments over the duration of the experiment. According to standard University of Illinois dairy farm protocols, at birth each calf was vaccinated with TSV-2 (Pfizer Inc., New York, NY) and First Defense (ImmuCell Corp., Portland, ME) and had its navel dipped in 7\% tincture of iodine solution (First Priority Inc., Elgin, IL). All calves were fed a minimum of $3.8 \mathrm{~L}$ of colostrum within $8 \mathrm{~h}$ of birth and received colostrum and transition milk for ad libitum intake through d 2 of life.

Calves were housed in individual hutches (Calf-Tel, Hampel Corp., Germantown, WI) through wk 8. From wk 8 to 10, calves were group housed by treatment in super hutches (Calf-Tel, Hampel Corp.). All hutches were placed on a crushed limestone base, followed by layers of corncobs and straw.

\section{Feeding and Management of Calves}

Experimental treatments compared low and high planes of nutrition during the milk replacer feeding period (varied by differences in amount and composition of milk replacer fed) and also compared 2 starter $\mathrm{CP}$ concentrations for calves receiving the higher plane of nutrition. The experimental treatments were constructed from the following feeds: a conventional milk replacer (20\% CP, $20 \%$ fat) used for the low amount of milk replacer (LMR), an enhanced milk replacer (28.5\% CP, $15 \%$ fat) used for the high amount of milk replacer (HMR), a conventional starter (CCS; $19.6 \%$ CP, DM basis), and a high-CP enhanced starter (HCS; $25.5 \%$ CP, DM basis). Milk replacers were formulated and manufactured by Milk Specialties Co. (Dundee, IL) and were not medicated. Deccox-M (Alpharma Health Division, Fort Lee, NJ) was added (4.7 g per $55 \mathrm{~kg}$ of BW) to individual nipple pails after reconstitution of the milk replacers. Starters (Table 1) were manufactured by Buckeye Nutrition (Dalton, OH).

Calves began treatments at $3 \mathrm{~d}$ of age. The $3 \mathrm{ex}-$ perimental treatments were 1$) \mathrm{LMR}+\mathrm{CCS}(\mathrm{n}=29$ calves), 2) HMR + CCS ( $\mathrm{n}=31)$, and 3) HMR + HCS ( $\mathrm{n}=29$ ). The LMR was reconstituted to $12.5 \%$ solids and fed at $1.25 \%$ of birth BW as DM daily in 2 feedings from wk 1 to 5 (through d 35) and at $0.625 \%$ of birth BW as DM once daily during wk 6 (d 36 to 42 ), which was the weaning transition. The HMR was reconstituted to $15 \%$ solids and fed at $1.5 \%$ of $\mathrm{BW}$ as DM during wk 1 and $2 \%$ of BW as DM during wk 2 to 5 , divided into 2 daily feedings. During the weaning transition at wk 6 (d 36 to 42), HMR was fed at $1 \%$ of BW as DM once daily. All calves were weaned at d 42 . Calves were fed at 0800 and $1500 \mathrm{~h}$ daily. Milk replacer refusals were measured daily to calculate milk replacer 
intakes. Water was available at all times for ad libitum intake. Calves were offered starter for ad libitum intake beginning on d 3 . Calves were initially offered $0.45 \mathrm{~kg}$ of starter daily, with amounts offered increasing by 0.23 $\mathrm{kg}$ as intake increased. Calf starter intake was recorded once daily after the morning milk replacer feeding.

\section{Health}

Calf health was monitored several times daily. Fecal scores were assigned and recorded once daily while calves were housed in individual hutches using the following scale: $1=$ firm, well formed (not hard), $2=$ soft, pudding-like, $3=$ runny, pancake batter, and $4=$ liquid, splatters. Calves with elevated fecal scores that appeared depressed (milk refusals, lowered head, drooping ears) were treated for diarrhea with electrolytes after the morning feeding until fecal score decreased and behavior returned to normal. Thus, depressed calves with diarrhea (fecal score $\geq 3$ ) received Entrolyte HE (Pfizer Animal Health, Exton, PA) $1 \mathrm{~h}$ post-feeding for the first $2 \mathrm{~d}$, followed by Advance Arrest (Milk Specialties Co.) for $3 \mathrm{~d}$.

\section{Body Growth and Measurements}

Calves were weighed at birth, before treatment assignment on d 3, and each Wednesday at $1300 \mathrm{~h}$. Withers height, length, and heart girth also were measured. Calculations of ADG of BW and stature were made from these measurements.

\section{Feed Analysis}

Milk replacers and starters were sampled weekly and composited monthly. Milk replacers were analyzed for concentrations of $\mathrm{CP}$, crude fat, $\mathrm{Ca}, \mathrm{P}, \mathrm{Mg}, \mathrm{K}, \mathrm{Na}, \mathrm{Fe}$, $\mathrm{Zn}, \mathrm{Cu}, \mathrm{Mn}$, and $\mathrm{Mo}$ and starters were analyzed for concentrations of $\mathrm{CP}, \mathrm{ADF}, \mathrm{NDF}, \mathrm{Ca}, \mathrm{P}, \mathrm{Mg}, \mathrm{K}, \mathrm{Na}$, $\mathrm{Fe}, \mathrm{Zn}, \mathrm{Cu}, \mathrm{Mn}$, and Mo by wet chemistry methods (www.dairyone.com/Forage/Procedures/default.htm) at a commercial laboratory (Dairy One Cooperative Inc., Ithaca, NY). The gross energy content of milk replacers and starters was determined by using an adiabatic bomb calorimeter (Parr Instrument Co., Moline, IL). The ME content of feeds was calculated from gross energy as described by NRC (2001).

\section{Statistical Analysis}

Data were subjected to ANOVA using the MIXED procedure in SAS (SAS Institute Inc., Cary, NC; version 9.1). Calf was defined as a random effect, whereas
Table 1. Ingredient composition of conventional calf starter (CCS) and high-CP starter (HCS)

\begin{tabular}{lcc}
\hline & \multicolumn{2}{c}{ Starter } \\
\cline { 2 - 3 } Ingredient (\% of DM) & CCS & HCS \\
\hline Pellet & 45.00 & 45.00 \\
Wheat middlings & 46.75 & 5.29 \\
Soybean meal & 34.43 & 77.48 \\
Dried distillers grains, corn & 10.00 & 5.00 \\
Calcium carbonate & 5.44 & 4.98 \\
Alfalfa, 17\% CP & - & 3.00 \\
21\% monocalcium phosphate & 1.78 & 2.12 \\
Salt & 0.70 & 0.70 \\
Dynamate & 0.50 & 11.56 \\
Vitamin E & 0.170 & 0.171 \\
Magnesium oxide & 0.128 & 0.025 \\
Vitamin A & 0.045 & 0.045 \\
Dairy trace mineral mix & 0.044 & 0.044 \\
Vitamin D & 0.006 & 0.006 \\
Copper sulfate & 0.003 & 0.002 \\
Cracked corn & 22.50 & 21.25 \\
Oats & 15.00 & 15.00 \\
Steam crimped corn & 12.50 & 13.75 \\
Molasses, cane & 5.00 & 5.00 \\
\hline
\end{tabular}

${ }^{1}$ The Mosaic Co. (Plymouth, MN).

treatment, sex, and treatment $\times$ sex were fixed effects. For variables with repeated measures, the model also contained the fixed effects of covariate (pretreatment measurement), time, sex, treatment, and all associated interactions. Covariance structures considered were compound symmetric, autoregressive order one, and unstructured. The covariance structure that gave the lowest Akaike information criterion was used (Littell et al., 1998), which was compound symmetry for growth measures (including ADG and gain:feed ratio) and autoregressive order one for intake variables. Initial measurements of BW, withers height, length, and heart girth collected at birth before treatments were assigned were used as covariates when analyzing the respective stature measurements. Treatment comparisons were made using 2 preplanned orthogonal contrasts: 1 ) conventional versus enhanced milk replacer treatments ( $\mathrm{LMR}+\mathrm{CCS}$ vs. HMR + CCS and HMR + HCS) and 2) conventional starter versus enhanced starter within the enhanced milk replacer groups (HMR + CCS vs. HMR + HCS). Therefore, the overall $P$-values for treatment are not presented. Least squares means and standard errors are reported. Significance was declared at $P<0.05$ and trends discussed when $0.05<P \leq$ 0.10 . In the instance of a significant treatment $\times$ time interaction $(P \leq 0.10)$, the PDIFF statement in SAS was used to determine differences between treatments at specific time points $(P \leq 0.05)$. A linear regression model for wk 7 ADG was developed using the GLM procedure in SAS and included the significant effects of 3-d preweaning starter DMI $(\mathrm{g} / \mathrm{d})$ and month. 
Table 2. Measured chemical composition of the experimental milk replacers used for low plane of nutrition (LMR) or high plane of nutrition (HMR)

\begin{tabular}{|c|c|c|}
\hline \multirow[b]{2}{*}{ Component } & \multicolumn{2}{|c|}{ Milk replacer } \\
\hline & LMR & HMR \\
\hline $\mathrm{DM}(\%)$ & 93.0 & 92.9 \\
\hline $\mathrm{CP}(\%$ of $\mathrm{DM})$ & 21.0 & 30.8 \\
\hline Crude fat $(\%$ of DM) & 22.4 & 14.4 \\
\hline TDN ( $\%$ of DM) & 112.0 & 79.5 \\
\hline $\mathrm{NE}_{\mathrm{M}}($ Mcal $/ \mathrm{kg})$ & 3.19 & 2.79 \\
\hline $\mathrm{NE}_{\mathrm{C}}(\mathrm{Mcal} / \mathrm{kg})$ & 2.31 & 2.00 \\
\hline $\mathrm{Ca}(\%$ of $\mathrm{DM})$ & 1.08 & 1.14 \\
\hline $\mathrm{P}(\%$ of $\mathrm{DM})$ & 0.70 & 0.71 \\
\hline $\mathrm{Mg}(\%$ of $\mathrm{DM}$ & 0.13 & 0.14 \\
\hline $\mathrm{K}(\%$ of $\mathrm{DM})$ & 1.95 & 1.72 \\
\hline $\mathrm{Na}(\%$ of $\mathrm{DM})$ & 0.77 & 0.79 \\
\hline $\mathrm{Fe}(\mathrm{mg} / \mathrm{kg})$ & 119 & 136 \\
\hline $\mathrm{Zn}(\mathrm{mg} / \mathrm{kg})$ & 124 & 105 \\
\hline $\mathrm{Cu}(\mathrm{mg} / \mathrm{kg})$ & 10.2 & 13.0 \\
\hline $\mathrm{Mn}(\mathrm{mg} / \mathrm{kg})$ & 56 & 54 \\
\hline Mo $(\mathrm{mg} / \mathrm{kg})$ & 0.65 & 0.80 \\
\hline Gross energy (Mcal $/ \mathrm{kg}$ of DM) & 5.31 & 5.07 \\
\hline $\mathrm{ME}(\mathrm{Mcal} / \mathrm{kg}$ of $\mathrm{DM})$ & 4.95 & 4.72 \\
\hline
\end{tabular}

\section{RESULTS}

\section{Nutrient Composition of Diets}

Ingredient composition of the starters is in Table 1. The measured chemical composition of the milk replacers and starters can be found in Table 2 and Table 3 , respectively. The LMR and HMR were formulated to contain 20 and $28 \% \mathrm{CP}$, respectively, and actual analyzed CP (DM basis) was 21 and $31 \%$, respectively. The CCS and HCS starters were formulated to contain 18 and $22 \% \mathrm{CP}$ on an as-fed basis. The measured $\mathrm{CP}$ contents were 20 and $26 \%$ on a DM basis, respectively.

\section{Intakes}

Mean intakes of milk replacer DM, CP, and ME were greater $(P<0.0001)$ for calves fed HMR as designed (Table 4). Preweaning intakes of starter DM $(P=$ $0.0002)$, starter $\mathrm{CP}(P=0.003)$ and starter $\mathrm{ME}(P=$ $0.0002)$ were greater for calves fed LMR. Total CP and ME intakes were greater $(P<0.0001)$ for calves fed HMR. Within calves fed HMR, preweaning intakes of starter CP $(P=0.02)$ were greater for calves fed HCS. For calves fed HMR, intakes of starter $\mathrm{CP}$ and $\mathrm{ME}$ were greater $(P<0.02)$ for calves fed HCS than for those fed CCS during wk 6 and 7 (data not shown).

Daily intakes were evaluated for the weaning period from d 29 to 49 (Figure 1). Calves received 2 daily feedings of milk replacer through d 35 and once-daily feeding from d 36 to 42 , with no milk replacer fed from d 43 onward. Mean intake of starter DM (1,094, 689, and $883 \mathrm{~g} / \mathrm{d}$ for calves fed LMR + CCS, HMR +
CCS, or HMR + HCS, respectively) was greater during the weaning period for calves fed LMR $(P=0.0002)$. Starter DMI was greater $(P<0.05)$ for calves fed LMR from d 34 to 42 (Figure 1A). Calves fed HMR + HCS had greater intakes of starter DM $(P<0.04)$ and CP $(P<0.0001)$ than calves fed HMR + CCS. Additionally, calves fed HMR + HCS consumed more $(P<0.05)$ starter DM from d 41 to 47 than did calves fed HMR + CCS. Calves fed LMR + CCS had lower $(P<0.0001)$ mean total intakes of $\mathrm{CP}(270,318$, and $405 \mathrm{~g} / \mathrm{d})$ from d 29 to 49 than calves fed HMR. Total CP intake was greater $(P<0.01)$ from d 36 to 49 for calves fed HMR + HCS (Figure 1B) compared with calves fed HMR + CCS. Total ME intake was greater $(P<0.001)$ from $\mathrm{d}$ 29 to 35 for calves fed LMR than for calves fed HMR (Figure 1C). From d 42 to 47, calves fed HMR + HCS had greater $(P<0.05)$ total ME intake than calves fed HMR + CCS. Daily total DMI (Figure 1D) was greater $(P<0.01)$ during d 29 to 35 for calves fed HMR than for those fed LMR, but was less $(P<0.05)$ during $\mathrm{d}$ 37 to 47 for calves fed HMR + CCS than for calves fed either of the other diets.

Interactions between sex and treatment during the weaning period were significant $(P=0.03)$. Mean daily intake of starter DM during the weaning period was greater $(P<0.05)$ for female calves $(1228 \mathrm{~g})$ fed LMR than male calves $(959 \mathrm{~g})$ fed LMR. Female calves fed LMR also had greater $(P<0.0001)$ starter DMI than females fed HMR during the weaning period. Male calves fed HMR + HCS had greater $(P=0.03)$ daily starter DMI than male calves fed HMR + CCS. Daily

Table 3. Measured chemical composition of conventional calf starter (CCS) and high-CP starter (HCS)

\begin{tabular}{lcc}
\hline & \multicolumn{2}{c}{ Starter } \\
\cline { 2 - 3 } Component & CCS & HCS \\
\hline DM (\%) & 88.7 & 89.0 \\
CP (\% of DM) & 19.6 & 25.5 \\
$\mathrm{ADF}(\%$ of DM) & 6.8 & 7.8 \\
$\mathrm{NDF}(\%$ of DM) & 18.4 & 14.9 \\
$\mathrm{TDN}(\%$ of DM) & 81.0 & 82.2 \\
$\mathrm{NE}(\mathrm{Mcal} / \mathrm{kg})$ & 2.00 & 2.05 \\
$\mathrm{NE}(\mathrm{Mcal} / \mathrm{kg})$ & 1.34 & 1.39 \\
$\mathrm{Ca}(\%$ of DM) & 1.57 & 0.84 \\
$\mathrm{P}(\%$ of DM) & 0.84 & 0.74 \\
$\mathrm{Mg}(\%$ of DM) & 0.34 & 0.31 \\
$\mathrm{~K}(\%$ of DM) & 1.02 & 1.27 \\
$\mathrm{Na}(\%$ of DM) & 0.21 & 0.20 \\
$\mathrm{Fe}(\mathrm{mg} / \mathrm{kg})$ & 341 & 319 \\
$\mathrm{Zn}(\mathrm{mg} / \mathrm{kg})$ & 116 & 101 \\
$\mathrm{Cu}(\mathrm{mg} / \mathrm{kg})$ & 25.6 & 25.8 \\
$\mathrm{Mn}(\mathrm{mg} / \mathrm{kg})$ & 93 & 57 \\
$\mathrm{Mo}(\mathrm{mg} / \mathrm{kg})$ & 2.9 & 3.6 \\
$\mathrm{Gross}$ energy $(\mathrm{Mcal} / \mathrm{kg}$ of DM) & 4.45 & 4.53 \\
$\mathrm{ME}(\mathrm{Mcal} / \mathrm{kg}$ of DM) & 3.16 & 3.21 \\
\hline
\end{tabular}


Table 4. Least squares means for daily intakes of DM, CP, and ME from milk replacer and starter during the milk-fed period from wk 1 to 5 for calves fed a low plane of nutrition from conventional milk replacer (LMR) or a high plane of nutrition from enhanced milk replacer (HMR), with either a conventional starter (CCS) or a high-CP starter (HCS)

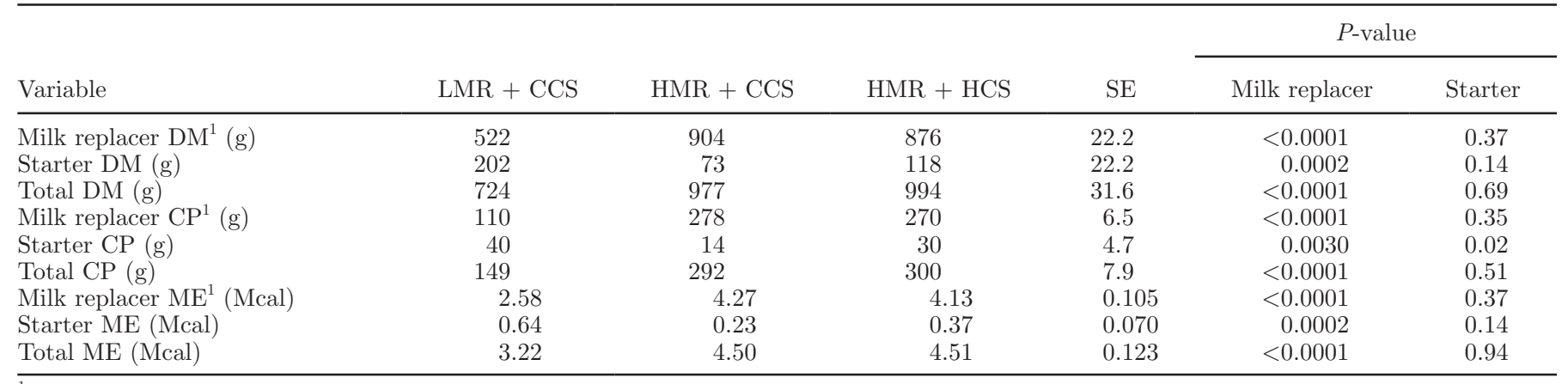

${ }^{1}$ Sex effect $(P<0.01)$.

total intake of ME was greater $(P=0.04)$ for male calves fed HMR + HCS (6.1 Mcal) than for all other groups $(5.1 \mathrm{Mcal})$. Treatment by sex interactions for daily total CP intake and total DMI (data not shown) followed similar trends due to corresponding differences between males and females for starter DMI and total ME intake.

\section{Growth}

Initial BW (Table 5) and stature measurements (data not shown) did not differ among treatments $(P$ $>0.1$ ). Repeated measures analysis revealed treatment by week interactions $(P<0.0001)$ for BW (Figure 2$)$ and withers height (Figure 3). Calf BW (Figure 2) was greater $(P=0.0001)$ for calves fed HMR than for those fed LMR, but the apparent advantage for calves fed HMR + HCS over those fed HMR + CCS did not reach significance $(P=0.11)$. Withers height increased more rapidly for calves fed HMR than those fed LMR, but starter had no effect in calves fed HMR (Figure 3). Similar relationships were found for body length and heart girth (data not shown).

Preweaning BW, withers height, body length, and heart girth (Table 5$)$ were greater $(P<0.001)$ for calves fed enhanced milk replacers. At 8 wk, which was the last measurement in individual housing, BW, withers height, body length, and heart girth were greater $(P$ $<0.01)$ for calves fed HMR than for those fed LMR (Table 6). Calves fed HMR + HCS had greater BW $(P=0.04)$ at 8 wk than calves fed HMR + CCS. At wk 10, final BW $(P<0.0001)$, withers height $(P<$ $0.0001)$, body length $(P=0.004)$, and heart girth $(P=$ $0.0003)$ were greater for calves fed HMR than for those fed LMR (Table 6). Calves fed HMR + HCS tended to have greater final $\mathrm{BW}(P=0.06)$ and had greater heart girth $(P=0.03)$ than calves fed HMR + CCS. Male calves fed HMR + HCS were heavier $(P=0.01)$ than female calves fed the same diet $(70.3$ and $66.1 \mathrm{~kg}$, respectively).

Mean ADG and gain-to-feed ratio were greater $(P<$ 0.0001) for calves fed HMR than for calves fed LMR. As determined in the repeated measures analysis, mean ADG over the 10 -wk study were $0.64,0.74$, and 0.80 $\mathrm{kg} / \mathrm{d}$ for treatments LMR + CCS, HMR + CCS, and HMR + HCS, respectively. The ADG was greater $(P$ $<0.0001)$ through wk 5 for calves fed HMR than for those fed LMR as shown in Figure 4. Calves fed HMR + HCS had greater $(P<0.02)$ ADG in wk 6 and 7 than calves fed HMR + HCS. Calves fed LMR had greater $(P<0.01)$ ADG in wk $7(0.89 \mathrm{~kg} / \mathrm{d})$ than calves fed HMR + CCS $(0.31 \mathrm{~kg} / \mathrm{d})$ or HMR + HCS $(0.60 \mathrm{~kg} / \mathrm{d})$. The ADG at wk 8 and 10 was not different among treatments or between sexes.

Feed efficiency (gain:feed ratio) was greater $(P<$ $0.05)$ from wk 1 to 3 and in wk $6(0.77,1.66$, and 1.45 $\mathrm{kg} / \mathrm{d}$ ) for calves fed HMR than for calves fed LMR (Figure 5). Overall, the preweaning gain:feed ratio was greater $(P<0.0001)$ for calves fed HMR than for those fed LMR (Table 5). Calves fed HMR + CCS had greater $(P<0.05)$ feed efficiency during wk 6 than calves fed HMR + HCS. Calves fed LMR + CCS had greater $(P<0.01)$ gain:feed ratio after weaning in wk 7 (Figure 5) than calves fed HMR + CCS or HMR + $\operatorname{HCS}(0.48,0.30$, and 0.34$)$.

We conducted linear regression analysis to determine whether postweaning ADG was related to preweaning starter intake. We evaluated several intervals of starter DMI during wh 5 and 6 , but the strongest relationship was between starter DMI during the last $3 \mathrm{~d}$ before complete weaning. This may be logical because starter DMI reached a plateau about $3 \mathrm{~d}$ after the second milk replacer feeding was discontinued on d 35 (Figure 1A). The regression analysis (Figure 6) revealed that ADG during the week after weaning (wk 7) was strongly associated $\left(\mathrm{R}^{2}=0.73\right)$ with 3 -d preweaning starter DMI 
(g/d). Preweaning starter DMI $(P<0.0001)$ and season $(P<0.01)$ were significant effects in the model, but sex and treatment were not significant.

\section{Calf Health}

Calves fed HMR had more fluid feces than those fed LMR $(P=0.01)$ as shown in Table 5. Calves fed LMR + CCS had fecal scores $>2$ for an average of 9 d, whereas calves fed HMR + CCS or HMR + HCS averaged 16 and $14 \mathrm{~d}$ of elevated scores $(P=0.004)$. However, the number of calves treated with electrolytes for diarrhea did not differ among treatments $(P>0.1)$. No calves were removed from the study.

\section{DISCUSSION}

The results for intake and growth of calves fed HMR in this trial were consistent with results of previously published experiments. Calves fed HMR had increased ADG and greater efficiency of gain during the milk feeding period as observed by others (Diaz et al., 2001; Jasper and Weary, 2002; Cowles et al., 2006; Hill et al., 2008). The ADG in our study were slightly greater than those reported by others for calves born on the farm where the increased amounts of milk replacer were fed with starter (Cowles et al., 2006; Hill et al., 2008). Increased feeding rates of milk replacer decreased consumption of starter during the milk feeding period, also in agreement with the previous literature (Hill et al., 2006; Cowles et al., 2006; Hill et al., 2008). Although feces were more fluid, calves fed HMR did not have impaired health status as demonstrated by no greater frequency of treatment for diarrhea.

The supply of MP was increased in the HCS treatment by increasing inclusion of soybean meal, primarily replacing wheat middlings and dried distillers grains (Table 1). Ruminal degradation of soybean meal was lower in calves than in mature ruminants and was lower at $2 \mathrm{wk}$ postweaning than at 4 or $8 \mathrm{wk}$ postweaning (Vazquez-Anon et al., 1993). Replacement of wheat middlings with soybean meal might have decreased microbial protein synthesis in the developing rumen, but previous measurements showed that ruminal microbial protein synthesis remained lower than in mature ruminants for 2 wk (Quigley et al., 1985) to 7 wk (Leibholz, 1975) after weaning. Therefore, although not measured directly, the greater CP content of HCS should have increased MP supply to the calves.

Consistent with our hypothesis, provision of the higher-CP HCS improved intake and growth of calves fed HMR compared with calves fed HMR + CCS, although effects were modest. However, starter intake was still lower than for calves fed LMR + CCS. Increased intake
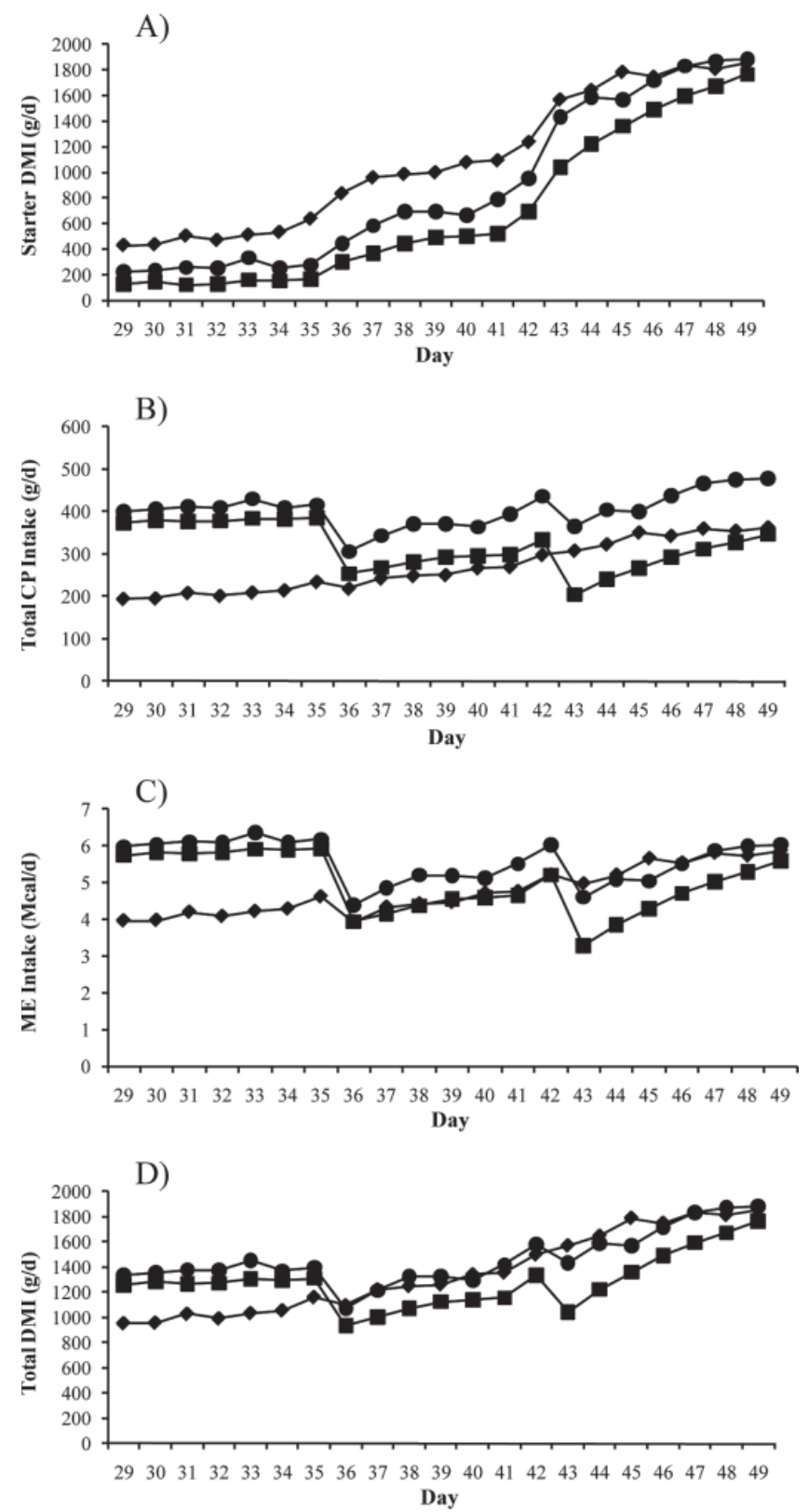

Figure 1. Mean daily intakes of starter DM (panel A), total CP (panel B; total of milk replacer plus starter), total ME (panel C; milk replacer plus starter), and total DM (panel D; milk replacer plus starter) from $1 \mathrm{wk}$ before to $1 \mathrm{wk}$ after weaning for calves fed a low intake of conventional milk replacer plus conventional starter (•), a high intake of enhanced milk replacer plus conventional starter $(\mathbf{\square})$, or a high intake of enhanced milk replacer plus a high-CP enhanced starter $(\bullet)$. Calves were fed milk replacer once daily starting on d 36 and were weaned on $\mathrm{d}$ 43. A: The SEM ranged from 61.9 to 65.0. Effects in model: milk replacer, $P=0.0002$; starter, $P=0.034$; day, $P<0.0001$; treatment $\times$ day, $P=0.001$. B: The SEM ranged from 14.3 to 14.97 . Effects in model: milk replacer, $P<0.0001$; starter, $P<0.0001$; day, $P<0.0001$; treatment $\times$ day, $P<0.0001$; sex, $P=0.45$; treatment $\times$ sex, $P=0.02$. C: The SEM ranged from 0.21 to 0.23 . Effects in model: milk replacer, $P=0.06$; starter, $P=0.05$; day, $P<0.0001$; treatment $\times$ day, $P<0.0001$; sex, $P=0.57$; treatment $\times$ sex, $P=0.04$ D: The SEM ranged from 65.2 to 68.4 . Effects in model: milk replacer, $P=$ 0.83 ; starter, $P=0.05$; day, $P<0.0001$; treatment $\times$ day, $P<0.0001$; sex, $P=0.80$; treatment $\times$ sex, $P=0.03$. 




Figure 2. Least squares means for weekly BW (kg) of calves fed a low intake of conventional milk replacer plus conventional starter ( ), a high intake of enhanced milk replacer plus conventional starter ( $\mathbf{\square})$, or a high intake of enhanced milk replacer plus a high-CP enhanced starter $(\bullet)$. The SEM ranged from 1.06 to 1.12. Effects in model: milk replacer, $P=0.0001$; starter, $P=0.11$; week, $P<0.0001$; treatment $\times$ week, $P<0.0001$; sex, $P=0.26$; treatment $\times$ sex, $P=0.03$.

of HCS provided greater amounts of $\mathrm{CP}$ and ME before and during the weaning process, which should benefit growth and health of calves during the weaning transition. In contrast to our results, Hill et al. (2007) found no benefit when starter MP supply was increased by several strategies for calves fed $680 \mathrm{~g} / \mathrm{d}$ of milk replacer solids; however, this feeding rate was about $21 \%$ lower than in our study (mean of $825 \mathrm{~g} / \mathrm{d}$ ).

Calf ADG were decreased during the time of weaning (wk 6 and 7) for calves fed HMR, although ADG were still positive. The degree to which calf growth rates slump around weaning may reflect development of the rumen and microbial digestion at the time of weaning (Terré et al., 2006, 2007; Hill et al., 2010). In this

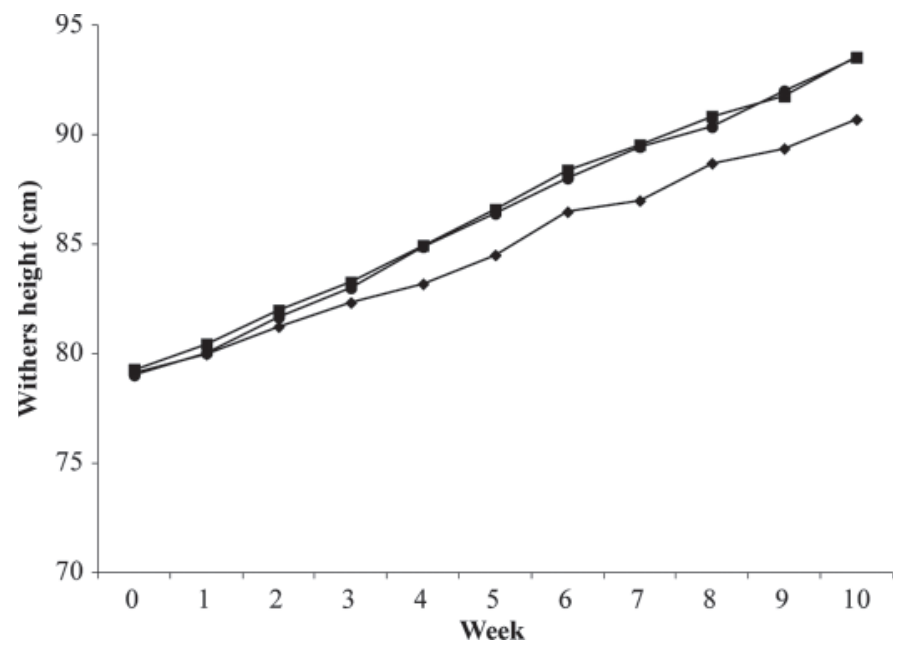

Figure 3. Least squares means for weekly withers heights $(\mathrm{cm})$ of calves fed a low intake of conventional milk replacer plus conventional starter $(\bullet)$, a high intake of enhanced milk replacer plus conventional starter ( $)$, or a high intake of enhanced milk replacer plus a high-CP enhanced starter $(\bullet)$. The SEM ranged from 0.40 to 0.42 . Effects in model: milk replacer, $P<0.0001$; starter, $P=0.61$; week, $P<0.0001$; treatment $\times$ week, $P<0.0001$.

experiment, calves were weaned at $42 \mathrm{~d}$ of age, without consideration of starter intake. We used linear regression analysis to investigate the relationship between mean starter DMI during the last $3 \mathrm{~d}$ milk replacer was fed (d 40 to 42) before weaning and the ADG 1 wk postweaning. Preweaning starter DMI accounted for $73 \%$ of the variation in postweaning ADG. This finding emphasizes the importance of starter intake before weaning and indicates that producers should monitor preweaning starter intake carefully to avoid weaningrelated slumps in growth. For example, to maintain a preweaning ADG of $1 \mathrm{~kg} / \mathrm{d}$ (Figure 4) the regression equation generated here (Figure 6) predicts that calves must be eating $1,377 \mathrm{~g} / \mathrm{d}$ of starter before weaning to

Table 5. Least squares means of initial and wk 5 BW, wk 5 stature measurements, and preweaning ADG, gain-to-feed ratio, fecal characteristics, and electrolyte intake for calves fed a low plane of nutrition from conventional milk replacer (LMR) or high plane of nutrition from enhanced milk replacer (HMR), with either a conventional starter (CCS) or a high-CP starter (HCS)

\begin{tabular}{|c|c|c|c|c|c|c|}
\hline \multirow[b]{2}{*}{ Variable } & \multirow[b]{2}{*}{$\mathrm{LMR}+\mathrm{CCS}$} & \multirow[b]{2}{*}{$\mathrm{HMR}+\mathrm{CCS}$} & \multirow[b]{2}{*}{$\mathrm{HMR}+\mathrm{HCS}$} & \multirow[b]{2}{*}{$\mathrm{SE}$} & \multicolumn{2}{|c|}{$P$-value } \\
\hline & & & & & Milk replacer & Starter \\
\hline BW (kg) & 55.3 & 67.0 & 67.7 & 0.82 & $<0.0001$ & 0.51 \\
\hline Mean ADG (kg/d) & 0.34 & 0.67 & 0.69 & 0.024 & $<0.0001$ & 0.66 \\
\hline Withers height $(\mathrm{cm})$ & 84.5 & 86.7 & 86.4 & 0.44 & 0.0003 & 0.70 \\
\hline Length $(\mathrm{cm})$ & 68.5 & 71.2 & 70.9 & 0.54 & 0.0002 & 0.67 \\
\hline Mean fecal score & 2.2 & 2.4 & 2.4 & 0.04 & 0.01 & 0.66 \\
\hline Electrolyte intake $(\mathrm{kg})$ & 0.1 & 0.2 & 0.1 & 0.02 & 0.17 & 0.25 \\
\hline Days with diarrhea ${ }^{1}$ & 1.5 & 2.9 & 2.8 & 0.5 & 0.05 & 0.89 \\
\hline
\end{tabular}

${ }^{1}$ Fecal score $=4$ (1 to 4 scale). 


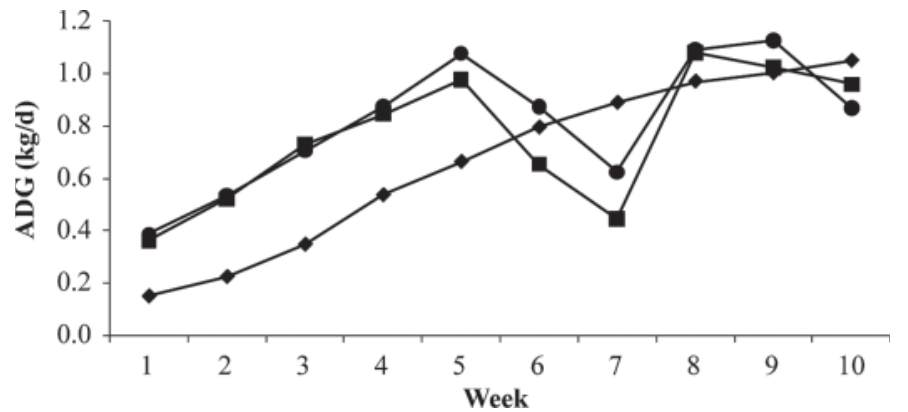

Figure 4. Least squares means for weekly ADG of calves fed a low intake of conventional milk replacer plus conventional starter (•), a high intake of enhanced milk replacer plus conventional starter (ם), or a high intake of enhanced milk replacer plus a high-CP enhanced starter $(\bullet)$. The SEM ranged from 0.063 to 0.067 . Effects in model: milk replacer, $P=0.0002$; starter, $P=0.10$; week, $P<0.0001$; treatment $\times$ week, $P<0.0001$.

maintain that rate of growth after weaning. Neither group of calves fed HMR achieved mean starter DMI of that magnitude before weaning (Figure 1A), although individual calves within each starter group did. These data indicate that more gradual reduction of milk solids intake (Khan et al., 2007) or weaning at an older age (de Passillé et al., 2011) might be required to optimize weaning success. The average age of weaning on US dairy farms was $8.2 \mathrm{wk}$ (NAHMS, 2007); perhaps easier weaning was a factor in producers' decision to delay weaning until that age.

Sex interacted significantly with dietary treatment during the weaning period from d 29 to 49, but unexpectedly, male calves did not have the greatest intakes. During this time, female calves fed LMR had greater intake of starter DM than male calves in the same treatment and female calves fed HMR. Variation in calf

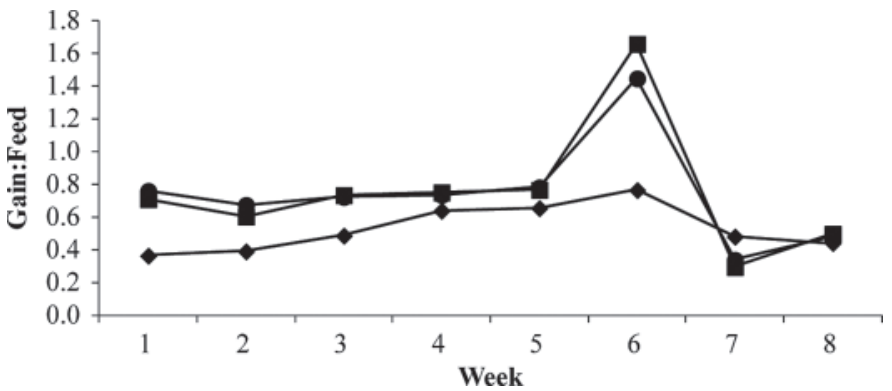

Figure 5. Least squares means for weekly gain to feed ratio of calves fed a low intake of conventional milk replacer plus conventional starter $(\bullet)$, a high intake of enhanced milk replacer plus conventional starter ( ), or a high intake of enhanced milk replacer plus a high-CP enhanced starter $(\bullet)$. The SEM ranged from 0.054 to 0.057 . Effects in model: milk replacer, $P<0.0001$; starter, $P=0.42$; week, $P<0.0001$; treatment $\times$ week, $P<0.0001$.

starter intake has been shown to account for over half of the variation in total BW gain in the same period (Kertz et al., 1979). Akayezu et al. (1994) found that male calves had greater feed efficiency and increased rate of gain than females before weaning, but starter DMI and total DMI were not affected by sex. The close relationship between starter intake and weight gain may explain observed growth differences between male and female calves fed HMR, whereas male and female calves fed LMR had similar rates of growth during the weaning period.

\section{CONCLUSIONS}

Our results describe the responses of dairy calves to increased feeding rate of milk replacer and greater starter CP content. Calves fed HMR had increased rate of gain and efficiency of gain through 10 wk of age.

Table 6. Least squares means of growth and body measurements during the last week in individual hutches (wk 8) and at the end of the study (wk 10) for calves fed a low plane of nutrition from conventional milk replacer (LMR) or high plane of nutrition from enhanced milk replacer (HMR), with either a conventional starter (CCS) or a high-CP starter (HCS)

\begin{tabular}{|c|c|c|c|c|c|c|}
\hline Variable & $\mathrm{LMR}+\mathrm{CCS}$ & HMR + CCS & $\mathrm{HMR}+\mathrm{HCS}$ & $\mathrm{SE}$ & \multicolumn{2}{|c|}{$P$-value } \\
\hline \multicolumn{7}{|l|}{ Wk 8} \\
\hline ADG $(\mathrm{kg} / \mathrm{d})$ & 0.97 & 1.08 & 1.09 & 0.075 & 0.20 & 0.90 \\
\hline Withers height $(\mathrm{cm})$ & 88.7 & 90.9 & 90.4 & 0.47 & 0.001 & 0.43 \\
\hline Length $(\mathrm{cm})$ & 72.4 & 74.6 & 75.0 & 0.63 & 0.003 & 0.66 \\
\hline $\mathrm{BW}^{1}(\mathrm{~kg})$ & 88.0 & 94.9 & 99.9 & 1.89 & $<0.0001$ & 0.06 \\
\hline ADG $(\mathrm{kg} / \mathrm{d})$ & 1.05 & 0.94 & 0.87 & 0.088 & 0.18 & 0.64 \\
\hline Withers height $(\mathrm{cm})$ & 90.8 & 93.7 & 93.6 & 0.53 & $<0.0001$ & 0.86 \\
\hline Length $(\mathrm{cm})$ & 76.6 & 78.9 & 78.8 & 0.65 & 0.004 & 0.89 \\
\hline Heart girth $(\mathrm{cm})$ & 101.9 & 104.4 & 106.1 & 0.74 & 0.0003 & 0.11 \\
\hline
\end{tabular}

${ }^{1}$ Sex $\times$ treatment interaction $(P<0.05)$. 


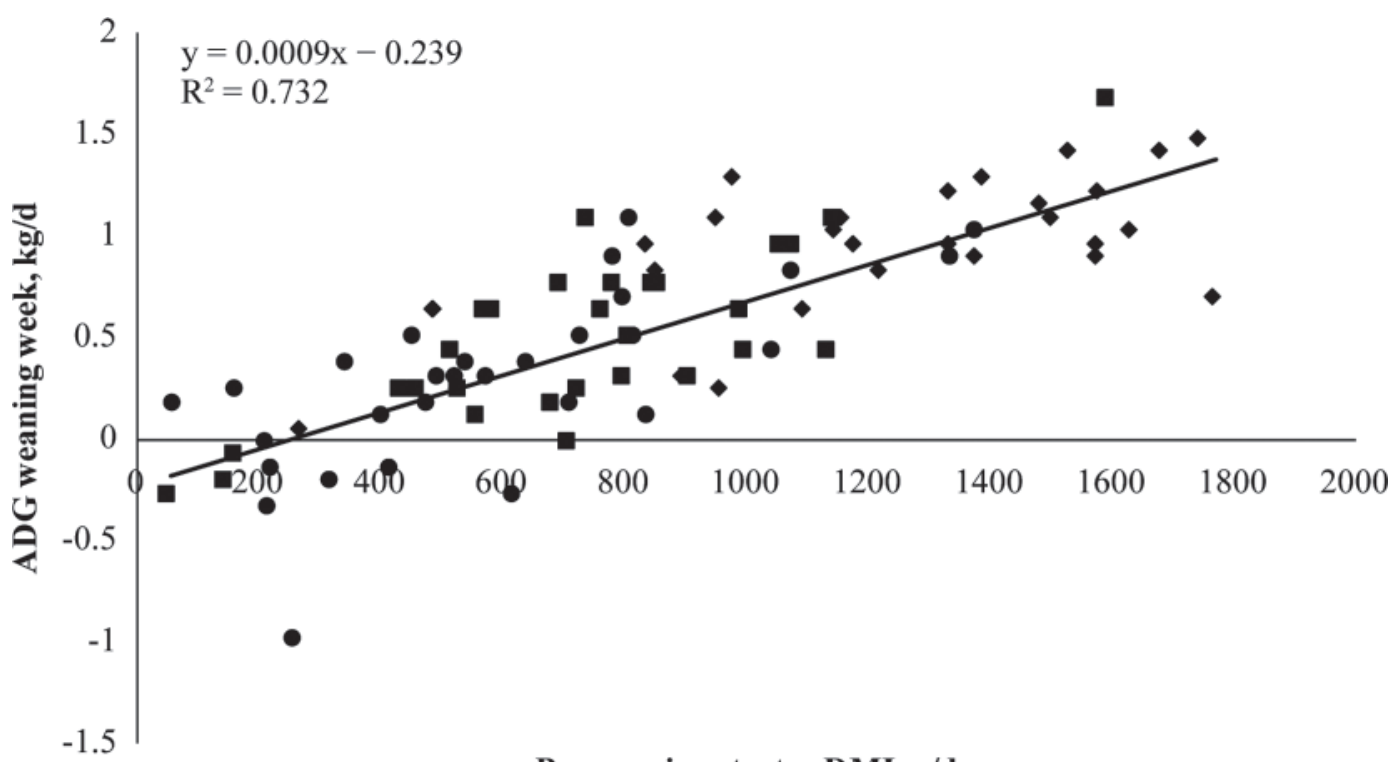

Preweaning starter DMI, g/d

Figure 6. Regression analysis of ADG (kg/d; y) during the week after weaning (wk 7) on mean daily starter DMI ( $\mathrm{g} / \mathrm{d}$, $\mathrm{x}$ ) during the last 3 $\mathrm{d}$ before weaning for calves fed a low intake of conventional milk replacer plus conventional starter $(\bullet)$, a high intake of enhanced milk replacer plus conventional starter $(\mathbf{\square})$, or a high intake of enhanced milk replacer plus a high-CP enhanced starter $(\bullet)$.

For calves fed HMR, those fed HCS maintained greater intakes of $\mathrm{CP}$ (and presumably MP) and ME during the transition around weaning, and had less slump in ADG and BW after weaning than calves fed the CCS. However, mean rate and efficiency of gain were not different between starters over the entire feeding period. Final withers height and body length were similar for both HMR treatments and were not affected by starter CP content. Starter DMI before weaning was a strong predictor of ADG during the week after weaning, indicating that monitoring starter DMI before weaning remains an important management practice to ease the weaning transition for calves on enhanced milk replacer programs. Our findings indicated that calves should consume at least $1 \mathrm{~kg}$ of starter DM daily before weaning to ensure continued postweaning growth, regardless of milk replacer regimen.

\section{REFERENCES}

Akayezu, J. M., J. G. Linn, D. E. Otterby, W. P. Hansen, and D. G. Johnson. 1994. Evaluation of calf starters containing different amounts of crude protein for growth of Holstein calves. J. Dairy Sci. $77: 1882-1889$.

Bartlett, K. S., F. K. McKeith, M. J. VandeHaar, G. E. Dahl, and J. K. Drackley. 2006. Growth and body composition of dairy calves fed milk replacers containing different amounts of protein at two feeding rates. J. Anim. Sci. 84:1454-1467.

Blome, R. M., J. K. Drackley, F. K. McKeith, M. F. Hutjens, and G. C. McCoy. 2003. Growth, nutrient utilization, and body composition of dairy calves fed milk replacers containing different amounts of protein. J. Anim. Sci. 81:1641-1655.

Cowles, K. E., R. A. White, N. L. Whitehouse, and P. S. Erickson. 2006. Growth characteristics of calves fed an intensified milk re- placer regimen with additional lactoferrin. J. Dairy Sci. 89:48354845.

Davis Rincker, L. E., M. J. VandeHaar, C. A. Wolf, J. S. Liesman, L. T. Chapin, and M. S. Weber Nielsen. 2011. Effect of intensified feeding of heifer calves on growth, pubertal age, calving age, milk yield, and economics. J. Dairy Sci. 94:3554-3567.

de Passillé, A. M., T. F. Borderas, and J. Rushen. 2011. Weaning age of calves fed a high milk allowance by automated feeders: Effects on feed, water, and energy intake, behavioral signs of hunger, and weight gains. J. Dairy Sci. 94:1401-1408.

Diaz, M. C., M. E. Van Amburgh, J. M. Smith, J. M. Kelsey, and E. L. Hutten. 2001. Composition of growth of Holstein calves fed milk replacer from birth to 105-kilogram body weight. J. Dairy Sci. $84: 830-842$.

Hill, S. R. K. F. Knowlton, K. M. Daniels, R. E. James, R. E. Pearson, and A. V. Capuco. 2008. Effects of milk replacer composition on growth, body composition, and nutrient excretion in preweaned Holstein heifers. J. Dairy Sci. 91:3145-3155.

Hill, T. M., J. M. Aldrich, R. L. Schlotterbeck, and H. G. Bateman II.. 2006. Effects of feeding calves different rates and protein concentrations of twenty percent fat milk replacers on growth during the neonatal period. Prof. Anim. Sci. 22:252-260.

Hill, T. M., J. M. Aldrich, R. L. Schlotterbeck, and H. G. Bateman II.. 2007. Protein concentrations for starters fed to transported neonatal calves. Prof. Anim. Sci. 23:123-134.

Hill, T. M., H. G. Bateman II, J. M. Aldrich, and R. L. Schlotterbeck. 2010. Effect of milk replacer program on digestion of nutrients in dairy calves. J. Dairy Sci. 93:1105-1115.

Hodgson, J. 1971. The development of solid food intake in calves. 5 . The relationship between liquid and solid food intake. Anim. Prod. 13:593-597.

Huber, J. T., A. G. Silva, O. F. Campos, and C. M. Mathieu. 1984. Influence of feeding different amounts of milk on performance, health, and absorption capability of baby calves. J. Dairy Sci. 67:2957-2963.

Jasper, J., and D. M. Weary. 2002. Effects of ad libitum milk intake on dairy calves. J. Dairy Sci. 85:3054-3058.

Jenny, B. F., H. J. Van Dijk, and L. W. Grimes. 1982. Performance of calves fed milk rations once daily at various fluid intakes and dry matter concentrations. J. Dairy Sci. 65:2345-2350. 
Kertz, A. F., L. R. Prewitt, and J. P. Everett Jr. 1979. An early weaning calf program: Summarization and review. J. Dairy Sci. 62:1835-1843.

Khan, M. A., H. J. Lee, W. S. Lee, H. S. Kim, S. B. Kim, K. S. Ki, J. K. Ha, H. G. Lee, and Y. J. Choi. 2007. Pre- and postweaning performance of Holstein female calves fed milk through step-down and conventional methods. J. Dairy Sci. 90:876-885.

Leaver, J. D., and N. H. Yarrow. 1972. Rearing of dairy cattle. 2. Weaning calves according to their concentrate intake. Anim. Prod. 14:161-165.

Leibholz, J. 1975. The development of ruminant digestion in the calf 1. The digestion of barley and soya bean meal. Aust. J. Agric. Res. 26:1081-1091.

Littell, R. C., P. R. Henry, and C. B. Ammerman. 1998. Statistical analysis of repeated measures data using SAS procedures. J. Anim. Sci. 76:1216-1231.

NAHMS (National Animal Health Monitoring System). 2007. Dairy 2007, Part I: Reference of Dairy Cattle Health and Management Practices in the United States, 2007. Publ. N480.1007. US Department of Agriculture: Animal and Plant Health Inspection Service: Veterinary Services (USDA:APHIS:VS), Centers for Epidemiology and Animal Health (CEAH), Fort Collins, CO
NRC. 2001. Pages 214-233 in Nutrient Requirements of Dairy Cattle. 7th rev. ed. Natl. Acad. Press, Washington, DC.

Quigley, J. D. III, C. G. Schwab, and W. E. Hylton. 1985. Development of rumen function in calves: Nature of protein reaching the abomasum. J. Dairy Sci. 68:694-702

Terré, M., M. Devant, and A. Bach. 2006. Performance and nitrogen metabolism of calves fed conventionally or following an enhanced growth feeding program during the preweaning period. Livest. Sci. 105:109-119.

Terré, M., M. Devant, and A. Bach. 2007. Effect of level of milk replacer fed to Holstein calves on performance during the preweaning period and starter digestibility at weaning. Livest. Sci. 110:82-88.

Vazquez-Anon, M., A. J. Heinrichs, J. M. Aldrich, and G. A. Varga 1993. Effect of postweaning age on rate of in situ protein disappearance in calves weaned at 5 weeks of age. J. Dairy Sci. $76: 2749-2757$.

Warner, R. G., W. P. Flatt, and J. K. Loosli. 1956. Dietary factors influencing the development of the animal's stomach. J. Agric. Food Chem. 4:788-792. 